\title{
Liquefaction assessments at shallow foundation building sites in the Central Business District of Christchurch, New Zealand
}

\author{
Jonathan D. Bray ${ }^{\mathrm{a}, *}$, Christopher S. Markham ${ }^{\mathrm{a}}$, Misko Cubrinovski ${ }^{\mathrm{b}}$ \\ ${ }^{a}$ University of California, Berkeley, CA 94720-1710, USA \\ ${ }^{\mathrm{b}}$ University of Canterbury, Christchurch, New Zealand
}

\section{A R T I C L E I N F O}

\section{Keywords:}

Case histories

Cyclic triaxial tests

Liquefaction

Performance based earthquake engineering, settlement

\begin{abstract}
A B S T R A C T
The 2010-2011 Canterbury earthquake sequence provides an exceptional opportunity to investigate the effects of varying degrees of liquefaction on the built environment. Significant ground settlements and building damage in the Central Business District (CBD) were observed for the Christchurch earthquake. The results of CPTs and soil index tests from exploratory borings performed in the CBD are combined with cyclic triaxial (CTX) test results to characterize the soil deposits at several buildings sites. Conventional one-dimensional liquefactioninduced ground settlement procedures do not capture shear-induced deformation mechanisms and the effects of ground loss due to sediment ejecta. Improved procedures are required. Nonlinear effective stress analyses using robust soil constitutive models calibrated through CTX tests provide a means for developing these procedures. The CTX tests estimate generally consistent cyclic resistances as the CPT-based methods for medium dense sands and silty sands; however, the CTX tests provide useful insights regarding pore water pressure response and strain development. Correlations and CTX tests performed on loose clean sands indicate that these specimens were disturbed by the sampling process. Interim findings from this ongoing study are presented, and preliminary recommendations for evaluating the seismic performance of buildings with shallow foundations at sites with liquefiable soils are provided.
\end{abstract}

\section{Introduction}

The 2010-2011 Canterbury earthquake sequence significantly affected Christchurch, New Zealand (NZ). The Christchurch earthquake caused 185 fatalities and many serious injuries. Earthquake shaking triggered localized-to-widespread, minor-to-severe liquefaction in the Christchurch area (e.g., [1-6]). Much of the damage of multi-story buildings was within the Central Business District (CBD). Nearly half of the buildings inspected within the $\mathrm{CBD}$ were marked as restricted access due to potential safety issues, and most of the CBD was cordoned off for over two years after the Christchurch earthquake. A majority of the 4,000 buildings within the CBD have been demolished, including most of the city's high-rise buildings. The seismic performance of modern multi-story buildings and buried utilities in the CBD were often significantly impacted by soil liquefaction.

The objective of this paper is to describe and explain some of the damage observed within the CBD. The performance of multi-story buildings during the Christchurch earthquake is emphasized. The important role of the CPT in characterizing the subsurface conditions and in providing data for evaluating the liquefaction hazard is discussed. Cyclic triaxial testing of relatively "undisturbed" soil specimens complement the CPT data and provide useful insights. The cyclic triaxial (CTX) test results provide important insights regarding the rapid transformation of soil from a stiff to a soft response as the excess pore water pressure rises beyond a threshold value. The laboratory test results are also useful in calibrating numerical simulations. Some important findings and preliminary recommendations for evaluating buildings with shallow foundations at potentially liquefiable sites are presented.

\section{Subsurface conditions within the CBD}

The Canterbury Plains are composed of complex alluvial fans deposited by eastward-flowing rivers draining the Southern Alps and discharging into Pegasus Bay on the Pacific Coast. Christchurch lies along the eastern extent of the Canterbury Plains, just north of the Banks Peninsula, the eroded remnant of the extinct Lyttelton Volcano, comprised of weathered basalt and Pleistocene loess [1]. The city was built on a historic floodplain of the Waimakiriri River, a large braided river that is now channelized approximately $25 \mathrm{~km}$ north of the CBD.

\footnotetext{
* Corresponding author.

E-mail addresses: jonbray@berkeley.edu (J.D. Bray), cmarkham@berkeley.edu (C.S. Markham), misko.cubrinovski@canterbury.ac.nz (M. Cubrinovski).
} 


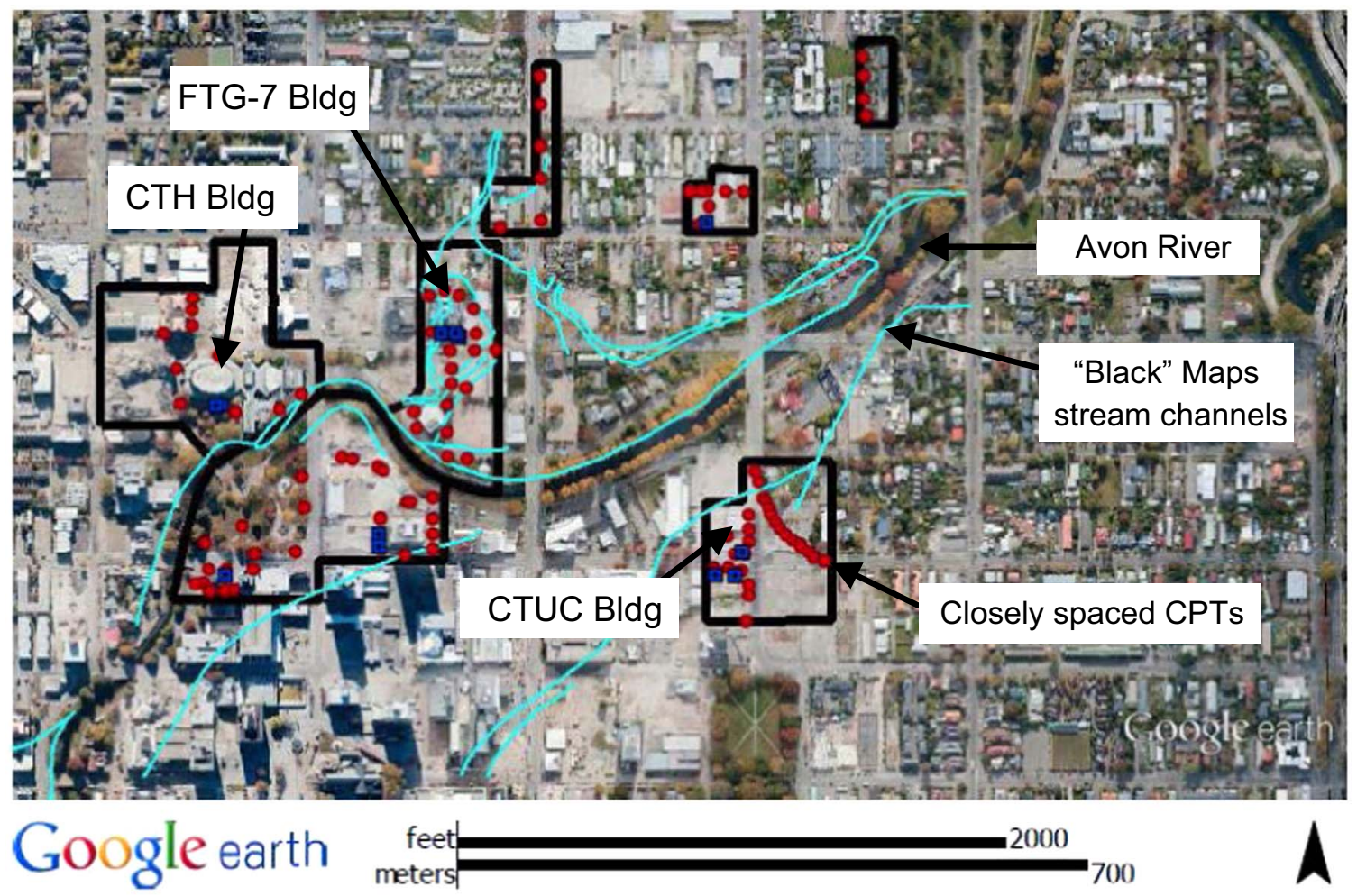

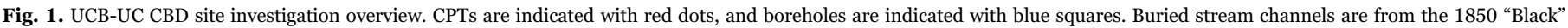
Maps [1]. The locations of the FTG-7, CTH and CTUC building sites, and the closely spaced CPTs are labeled.

The Waimakiriri River regularly flooded Christchurch prior to the construction of levees and river realignment carried out shortly after the city was established in the 1850s [7,8]. The 1850 "Black" Maps depict several buried stream channels through the CBD, some of which are shown on Fig. 1 [1]. The subsurface conditions in the CBD are highly variable floodplain deposits with alternating layers of sands and gravels with overbank deposits of silty soils and some peat deposits..

There are three geological formations of primary interest in foundation engineering within the CBD: the Springston Formation, Christchurch Formation, and Riccarton Gravels. The Springston Formation was deposited during the last 3000 years and is the shallowest of the three formations. It consists of three lithologic units [7]: 1) gravels deposited in old flood channels of the Waimakariri River; 2) overbank alluvial silt and sandy silt; and 3) peat deposits formed in marshland. The Christchurch Formation consists of beach, estuarine, lagoon, dune, and coastal swamp deposits composed of gravel, sand, silt, clay, shells, and peat, and its top is found at a depth of typically 7-10 m within the CBD. It is a post-glacial deposit and likely less than 6500 years old near the maximum inland extent of the postglacial marine transgression [7], which likely extended across the CBD based on the presence of shells observed in soil samples [9]. The Riccarton Gravels are beneath the Christchurch Formation and consist of well-graded brown or blue-grey gravels up to cobble size. This 10$20 \mathrm{~m}$ thick formation is the uppermost confined gravel aquifer in coastal northern Canterbury and is typically about $18-30 \mathrm{~m}$ below the ground surface in the CBD $[7,9]$.

Two spring fed rivers, the Avon and Heathcote, meander through Christchurch and discharge into an estuary east of Christchurch. The Avon River, labeled in Fig. 1, meanders through the CBD, while the Heathcote River flows south of the CBD. Much of the observed moderate-to-severe liquefaction within and to the east of the CBD occurred near the Avon River during the Canterbury earthquakes. The groundwater table is generally within $1-3 \mathrm{~m}$ of the ground surface within the CBD.

Following the Christchurch earthquake, the Earthquake
Commission of New Zealand (EQC) instigated a general subsurface investigation study of the CBD, which was organized by Tonkin \& Taylor, Ltd. (T+T), that included 151 CPTs, 48 soil exploratory boreholes with index testing, $45 \mathrm{~km}$ of geophysical surveys, and installation of piezometers (New Zealand Geotechnical Database [10]). The UC Berkeley (UCB) - Univ. of Canterbury (UC) research team performed 107 CPTs and 13 exploratory boreholes, most of which are shown in Fig. 1, to characterize 23 building sites within six study zones. The structures in their study consisted of multi-story buildings on shallow and deep foundations and displayed interesting engineering performance characteristics.

A shallow layer of dense gravelly soils prevented the advancement of the conventional $10 \mathrm{~cm}^{2}$ A.P. van den Berg cone with a $14 \mathrm{t}$ CPT truck in several areas within the CBD (e.g., near Victoria Square). To overcome this issue, Mr. Iain Haycock of McMillan Drilling Services Ltd. (McMillan) developed a pre-collaring system to enable CPT profiling below dense gravelly soils layers [5]. The pre-collaring system was a steel dual tube system consisting of threaded steel outer casing with a nominal outer diameter (OD) of $69.9 \mathrm{~mm}$ and steel inner rods with a nominal OD of $31.8 \mathrm{~mm}$ (see Fig. 2a). At the base of the inner rod string was a conical steel tip that was designed to fit through the outer casing shoe. The dual tube assembly was then driven using a hydraulic hammer and direct push with a larger CPT truck with a selfweight of approximately $22 \mathrm{t}$. The CPTs that incorporated pre-collaring were performed as follows:

1) The cone was advanced per ASTM D5778-07 until refusal was encountered;

2) To advance to a greater depth, the CPT rods and probe were extracted from the hole;

3) Casing was then advanced using a hydraulic hammer in combination with direct push until the hydraulic ram gauge pressure was judged to be low enough to resume with a conventional cone;

4) The inner casing rods were extracted leaving only the outer casing rods in the hole; 


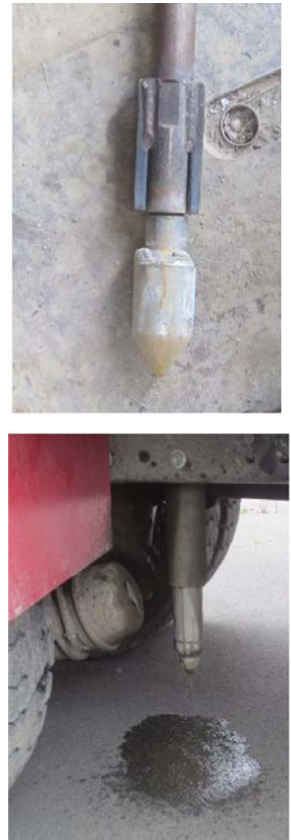

(a)
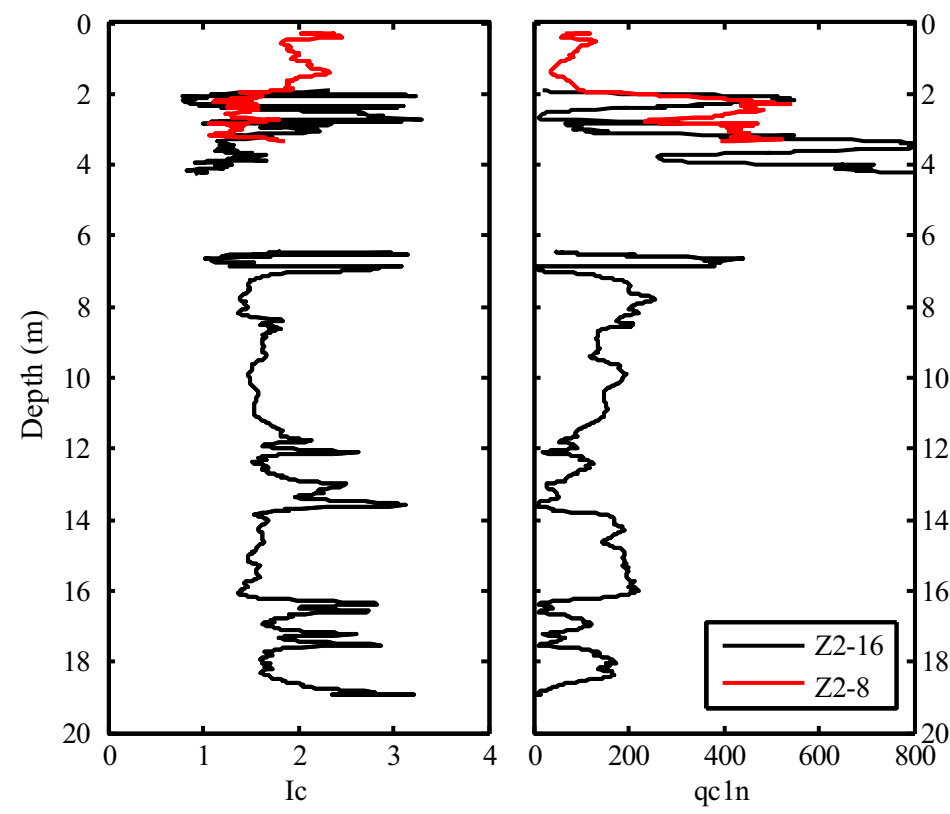

(b)

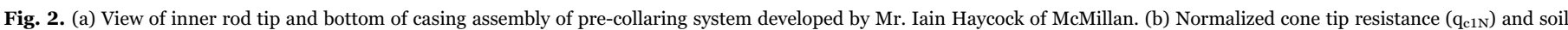

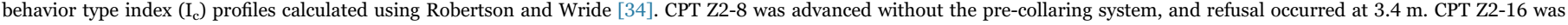
advanced later using the pre-collaring system to the full intended depth. The distance between the CPTs was approximately $5 \mathrm{~m}$ (modified from Bray et al. [5]).

5) The CPT cone and rod string was re-installed into the hole to the depth of the bottom of casing;

6) The CPT was resumed. If necessary, these steps were repeated.

The McMillan pre-collaring system generally had success in penetrating the dense gravelly soils of the type that caused premature refusal during the earlier attempts with the conventional CPT equipment. Representative CPT results from tests with and without the precollaring system are shown in Fig. 2b. CPT Z2-8 was performed in July 2011 without the pre-collaring system, and refusal was encountered at a depth of approximately $3.4 \mathrm{~m}$. CPT Z2-16, which is located approximately $5 \mathrm{~m}$ from CPT Z2-8, was performed in March 2013 with the McMillan pre-collaring system and reached the target depth of $19.1 \mathrm{~m}$.

Later, tests in this area of the CBD were performed by Fugro BTW Ltd. (Fugro) with a robust $15 \mathrm{~cm}^{2}$ cone manufactured by Fugro Engineers B.V. using a $20 \mathrm{t}$ CPT truck. This cone with this equipment could be pushed through materials with uncorrected tip resistances slightly greater than $80 \mathrm{MPa}$ if the rod remained nearly vertical. If the cone deflected off gravel-sized particles and was no longer within a few degrees of vertical, the test was stopped. However, this occurred infrequently. The CPTs performed using the Fugro system with the $15 \mathrm{~cm}^{2}$ cone were also generally successful in penetrating through areas with layers of dense gravelly materials. Thus, the CPT could be employed throughout the CBD with these CPT systems.

Due to its relative speed and superior standardization, the CPT should be preferred over the Standard Penetration Test (SPT) in the sandy and nonplastic silty soils that are prevalent in Christchurch. The SPT data should be used with caution due to the lack of standardization and documentation of the SPT systems used in Christchurch. The New Zealand Geotechnical Database (NZGD) provides CPT and SPT data as well as other subsurface data. The SPT blow count data, however, are often difficult to interpret, because sufficient details on the SPT system used are not provided. If the SPT is to be used, energy measurements should be performed (e.g., [11]). Large variations in the delivered energy are possible, even with automatic trip hammer systems. It is relatively easy and inexpensive to measure energy blow-by-blow using accelerometers and strain gauges to determine rod velocity and strain to calculate energy (ASTM D-4633). The use of SPT data from systems in which its energy has not been measured on site should be avoided. However, the retrieval of soil samples is critically important to supplement the CPT results. For example, many of the fine sands of Christchurch are not well characterized solely by soil behavior type index $\left(\mathrm{I}_{\mathrm{c}}\right)$ or Fines Content (FC). Instead, particle shape, which in many cases is subangular (see Fig. 3), may be equally important to particle size distribution and other soil index properties..

In addition to advancing CPTs adjacent to buildings, a line of 15 CPTs spaced about $10 \mathrm{~m}$ apart were advanced in a parking lot at the northeast corner of the intersection of Armagh and Madras streets to characterize the variability in soil conditions over relatively short distances $[4,5]$. Severe liquefaction (as defined by van Ballegooy et al. [6]) in the form of extensive amounts of ejecta and localized ground

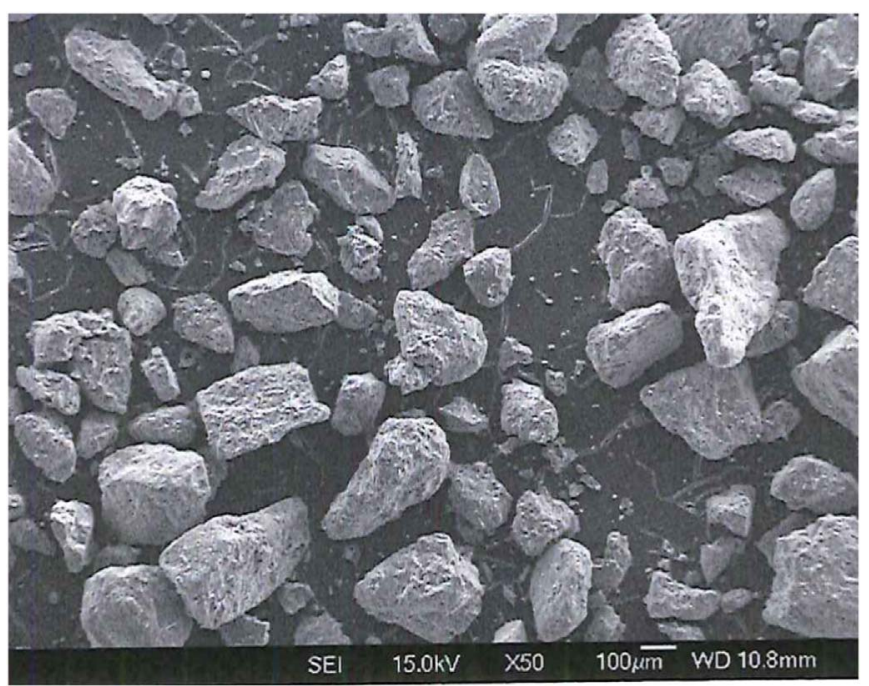

Fig. 3. Representative grain shape of a Christchurch sand (from Tonkin+Taylor, Ltd. Personal Communication 2014). 
cracking and settlement was observed over a 50-m wide zone after the 22 February (FEB) 2011 earthquake [1]. The shallowest layer within this narrow zone of observed liquefaction is composed of silty sand and sandy silt (SM/ ML) with a $\mathrm{q}_{t}$ generally less than $5 \mathrm{MPa}$ and $\mathrm{I}_{\mathrm{c}}$ between 2.0 and 2.5. Samples from a nearby borehole indicated a FC of about $50 \%$ for this layer. The next layer was a clean sand to gravelly sand (SP) with $\mathrm{q}_{\mathrm{t}}$ greater than $20 \mathrm{MPa}$ and often greater than $30 \mathrm{MPa}$ and $\mathrm{I}_{\mathrm{c}}$ between 1.0 and 1.5. Clean to silty sands of varying penetration resistance, but typically with $\mathrm{q}_{\mathrm{t}}$ greater than $10 \mathrm{MPa}$ followed the dense SP layer. The portion of the SM/ML layer that was below the groundwater table should have liquefied based on the median estimated PGA from Bradley and Hughes [12] during the 22 FEB 11 earthquake using state-of-the-practice liquefaction triggering procedures [4]. Outside of the zone of ground failure, the shallow liquefiable SM/ML layer was not found; instead, the denser SP layer was found below the groundwater. The shallow liquefiable SM/ML layer, when present in the soil profile, was often the critical layer in the observed liquefaction in the CBD. Its thickness below the groundwater table varied considerably over relatively short distances [4].

\section{Earthquake shaking and damage within the CBD}

Ground shaking was recorded at four strong motion stations within the CBD during the Canterbury earthquakes. The geometric mean horizontal peak ground accelerations (PGA) recorded at the stations are provided in Table 1 for five earthquakes. Two of these PGA values (i.e., CBGS and CCCC stations for the 22 FEB 2011 Christchurch earthquake) may have been increased by liquefaction-induced cyclic mobility [12]; it is difficult to assess what the values would have been without liquefaction, so the values are presented as recorded. Median (i.e., $\left.\mathrm{PGA}_{50}\right), 16 \%\left(\mathrm{PGA}_{16}\right)$, and $84 \%\left(\mathrm{PGA}_{84}\right)$ values of $\mathrm{PGA}$ estimated by Bradley and Hughes [13] are used in this study to evaluate liquefaction triggering and its effects within the CBD. The 22 FEB 2011 Christchurch $\mathrm{M}_{\mathrm{w}} 6.2$ earthquake produced the most intense ground shaking in the CBD, because the source-to-site distances (R) were only 3-6 km. Its PGA values were twice those recorded during the larger magnitude, but more distant $(\mathrm{R}=18-20 \mathrm{~km})$, 4 September (SEP) 2010 Darfield $\mathrm{M}_{\mathrm{w}} 7.1$ earthquake. The PGAs recorded in the CBD during the Darfield event are similar to those recorded during the 26 December (DEC) $2010 \mathrm{M}_{\mathrm{w}}$ 4.8, 13 June (JUN) $2011 \mathrm{M}_{\mathrm{w}} 6.0$ (which occurred $80 \mathrm{~min}$ after a 5.3 event), and 23 DEC $2011 \mathrm{M}_{\mathrm{w}} 5.9$ events (which occurred $80 \mathrm{~min}$ after a 5.8 event). The PGA values of the dozens of other $\mathrm{M}_{\mathrm{w}} 5+$ events are lower than those recorded during these events.

The 22 FEB 2011 Christchurch earthquake produced liquefaction over large areas in the CBD. The 4 SEP 2010 Darfield and 13 JUN 2011 earthquakes also produced localized areas of liquefaction in some areas of the CBD. Significant liquefaction during the 23 DEC 2011 earthquake was not observed, and no liquefaction was observed in the CBD from the 26 DEC 2010 earthquake. Cubrinovski et al. [1] and Bray et al. [4] present key observations of building and ground performance in the CBD following the Christchurch earthquake.

\section{High quality sampling and cyclic triaxial testing procedures}

CPT soundings in conjunction with state-of-the-practice liquefaction assessment procedures have been used as the primary tools to evaluate liquefaction triggering and its effects in Christchurch following the Canterbury earthquake sequence (e.g., $[4,6])$. Performance based earthquake engineering, however, often requires laboratory testing of key soil strata to calibrate constitutive models for advanced numerical simulations. In this phase of the UCB-UC study, high quality sampling was undertaken to retrieve test specimens for cyclic triaxial testing.

Block sampling or ground freezing sampling techniques have been shown to provide high quality laboratory specimens (e.g., [14,15]). However, the use of block sampling on the soils well below the shallow groundwater table in Christchurch was impractical, and ground freezing sampling technology was not available in New Zealand. In this study, the Dames \& Moore (DM) hydraulic fixed piston sampler [16] and the Gel-Push (G-P) sampler [17] were employed. Testing conducted on specimens retrieved in the CBD using the DM sampler is discussed in this paper.

High quality samples of silts and clays have been obtained previously using the DM hydraulic fixed piston sampler [16]. However, the DM sampler has not been proven to retrieve high quality samples of sands and nonplastic silty sands, which are the predominant soils in Christchurch. Three specimen quality evaluation approaches were employed in this study: 1) drilling and sampling notes and visual inspection, 2) comparison of laboratory relative density $\left(D_{r}\right)$ with estimates from CPT correlations, and 3) comparison of field measured and lab measured shear wave velocity $\left(\mathrm{V}_{\mathrm{s}}\right)$. Lab measured cyclic resistance ratios (CRR) were also compared with those estimated using CPT liquefaction triggering correlations to discern if the cyclic responses of the lab specimens were consistent with those expected based on established CPT-based procedures.

Soil exploratory borings were advanced using a tri-cone sidedischarge drill bit in a cased borehole with drilling mud. The DM is an Osterberg-type hydraulic fixed piston sampler that can retrieve relatively "undisturbed" soil samples (Fig. 4). The DM sampler uses thin walled brass tubes of constant internal diameter, ID $=61.2 \mathrm{~mm}$, and outside diameter, OD $=63.5 \mathrm{~mm}$. The tubes are pushed into the soil a length of $450 \mathrm{~mm}$ using the pressure provided by the circulation mud. Friction between the soil and the tube was minimized by using smooth brass tubes. The area ratio, defined by Horslev [18] as $\mathrm{C}_{\mathrm{a}}$ $=100 \cdot\left(\mathrm{OD}^{2}-\mathrm{ID}^{2}\right) / \mathrm{ID}^{2}$, is $7.6 \%$ for the DM brass tubes. Following sampling, tubes were sealed, placed upright in a specially designed box, and then carefully transported to the University of Canterbury laboratory for testing..

Test specimens were prepared from sample tubes with high recovery (typically $\geq 95 \%$ ) retrieved below the groundwater table and assumed to be saturated. The bottom $50 \mathrm{~mm}$ and upper $100 \mathrm{~mm}$ of each tube sample were assumed to be too disturbed for testing, so that a maximum of two 135-140-mm-high test specimens were obtained from each DM tube. Extrusion length was minimized by cutting tubes to the desired height. After installing stiffening rings on the tube above

Table 1

Recorded PGAs in the CBD during five 2010-11 Canterbury earthquake events.

\begin{tabular}{|c|c|c|c|c|c|c|c|}
\hline \multirow[t]{2}{*}{ Date } & \multirow[t]{2}{*}{$\mathrm{M}_{\mathrm{w}}$} & \multicolumn{4}{|c|}{ Recorded Geometric Mean PGA (g) in CBD } & \multirow[t]{2}{*}{ Median PGA (g) } & \multirow[t]{2}{*}{$\mathrm{PGA}_{50}(\mathrm{~g})[11]$} \\
\hline & & CBGS & $\mathrm{CCCC}$ & CHHC & REHS & & \\
\hline 4 SEP 2010 & 7.1 & 0.17 & 0.21 & 0.18 & 0.25 & 0.20 & 0.22 \\
\hline 26 DEC 2010 & 4.8 & 0.25 & 0.22 & 0.16 & 0.24 & 0.21 & - \\
\hline 22 FEB 2011 & 6.2 & 0.48 & 0.42 & 0.35 & 0.51 & 0.44 & 0.45 \\
\hline 13 JUN 2011 & $6.0^{\mathrm{a}}$ & 0.16 & - & 0.21 & 0.29 & 0.21 & 0.23 \\
\hline 23 DEC 2011 & $5.9^{\mathrm{a}}$ & 0.20 & 0.18 & 0.21 & 0.30 & 0.22 & 0.20 \\
\hline
\end{tabular}

\footnotetext{
${ }^{\text {a }}$ These events were preceded by smaller earthquakes that likely generated excess pore water pressure.
} 

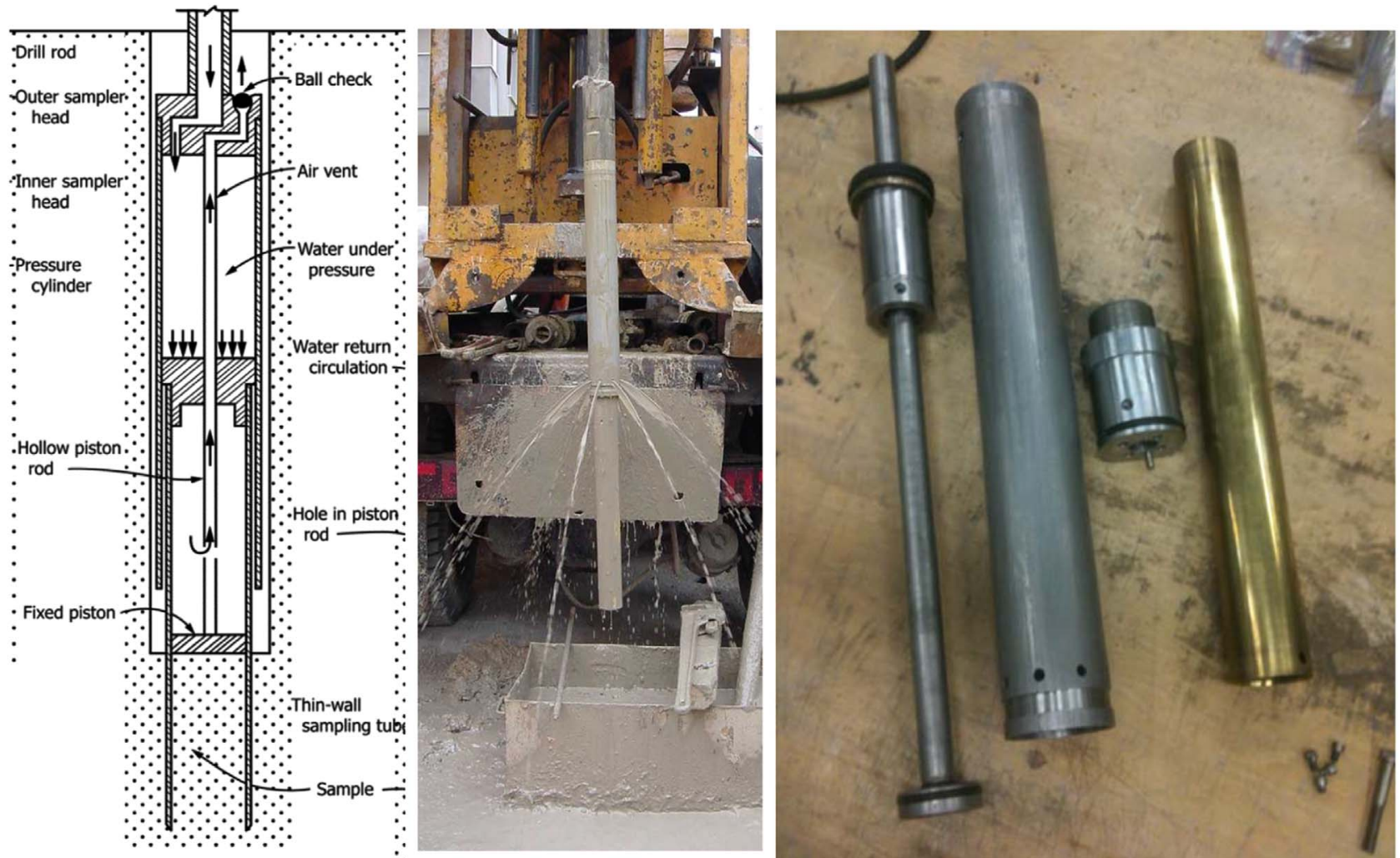

Fig. 4. Schematic of hydraulic fixed piston sampler (from ASTM D6519-08) and photographs of the Dames \& Moore hydraulic fixed-piston sampler with thin-walled brass tube.

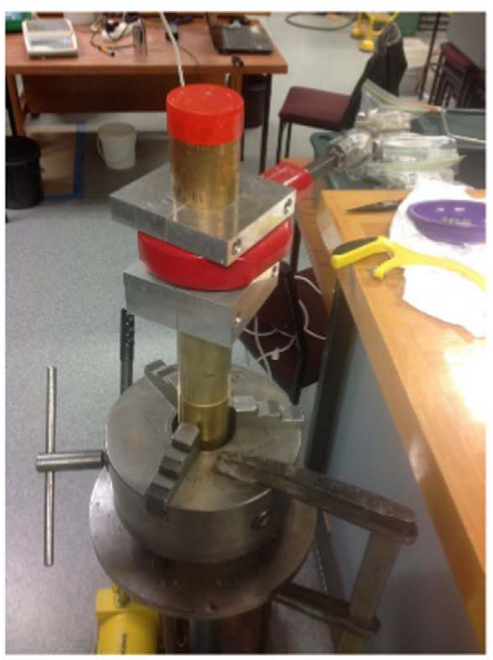

(a)

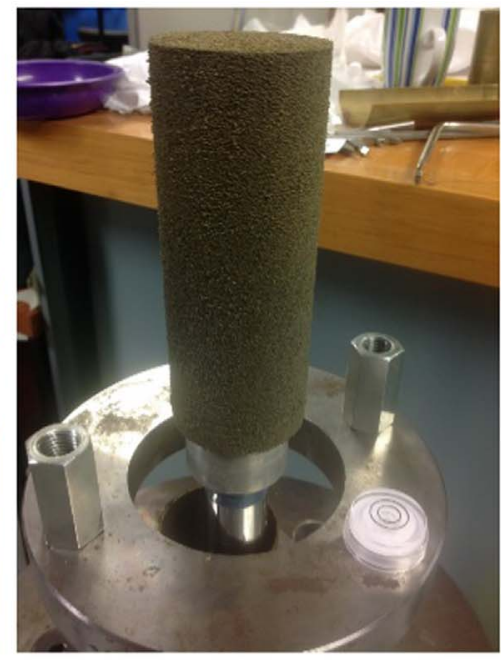

(b)

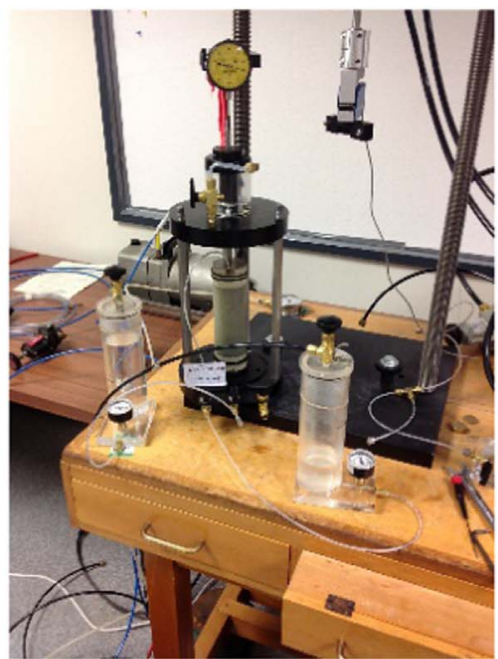

(c)

Fig. 5. Triaxial specimen preparation: (a) cutting tube, (b) specimen extrusion, and (c) placement in test device.

and below the location of the intended cut, a large-diameter pipe cutter was slowly rotated around the sample tube to cut it (Fig. 5a). The test specimen was extruded from the tube in the same direction as the soil first entered the tube using a hydraulic jack (Fig. 5b). It was visually inspected to ensure it was relatively undisturbed. Following the placement and securement of a flexible latex membrane around each specimen, an internal vacuum of $10-15 \mathrm{kPa}$ was applied to each specimen to allow for set-up of the triaxial chamber (Fig. 5c). Flushing of de-aired water through each specimen was attempted using differential vacuum, which was necessary for the saturation of the coarser-grained sand specimens. Subsequent specimen saturation was achieved through vacuum saturation (extraction) followed by back pressure saturation so that B-values larger than 0.95 were achieved (most B-values were $\geq 0.97$ )..

Estimated field and laboratory relative density $\left(D_{r}\right)$ values of test specimens were compared to gain insights into possible volumetric strains induced during the sampling and specimen preparation process when $\mathrm{FC}$ were less than $50 \%$. The minimum and maximum void ratio $\left(\mathrm{e}_{\min }\right.$ and $\mathrm{e}_{\max }$ ) for soil specimens with $\mathrm{FC}<50 \%$ were found using the Japanese Standard method (JIS A 1224:2000) so that $D_{\text {r-Lab }}$ could be calculated. $\mathrm{D}_{\mathrm{r} \text {-Field }}$ was estimated from various $\mathrm{CPT}-\mathrm{D}_{\mathrm{r}}$ correlations (e.g., $[19,20])$. These correlations require the use of a normalized equivalent clean-sand penetration resistance (e.g., $\mathrm{q}_{\mathrm{c} 1 \mathrm{Ncs}}$ [21]), which were estimated based on data from CPTs typically $2 \mathrm{~m}$ from each borehole. The estimated values of $\mathrm{D}_{\mathrm{r} \text {-Lab }}$ tended to be higher than values of $\mathrm{D}_{\mathrm{r} \text {-Field }}$ for specimens with low equivalent penetration 


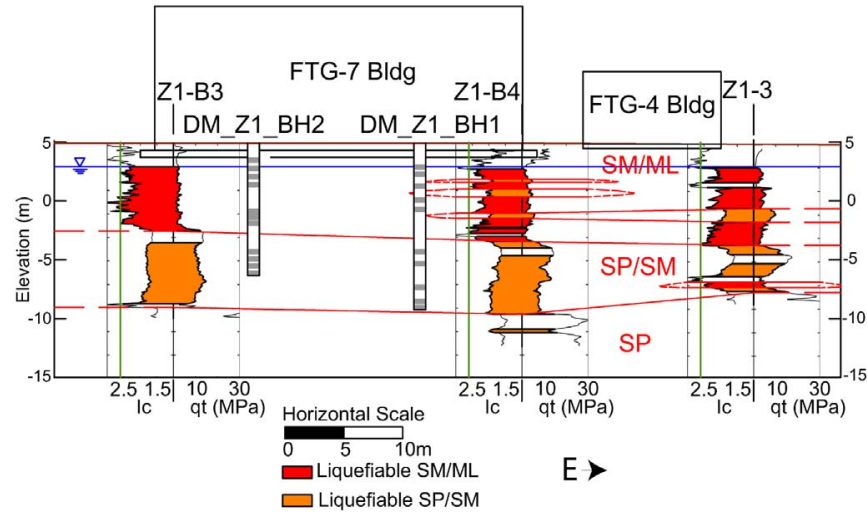

Fig. 6. Subsurface profile along southern edge of Building FTG-7 (oriented W-E); depths of retrieved "undisturbed" soil samples shown in grey-tone on boring logs; shaded areas indicate $\mathrm{FS}_{1}<1.0$ based on the Robertson and Wride procedure [34] using $\mathrm{PGA}_{50}$ $=0.45 \mathrm{~g}$ from Bradley and Hughes [13] for the 22 FEB 11 Christchurch earthquake (modified from Zupan [27]).

resistance (i.e., $\mathrm{q}_{\mathrm{c} 1 \mathrm{Ncs}}<60$ ). This discrepancy suggests that the sampling and specimen preparation procedures likely densified the loose clean sands prior to testing.

In addition, $V_{s}$ was measured in five of the laboratory CTX test specimens using bender elements. Direct field measurements of $\mathrm{V}_{\mathrm{S}}$ were not available at the CBD sites. However, a robust Christchurchspecific CPT- $\mathrm{V}_{\mathrm{s}}$ correlation developed by McGann et al. [22] was used to obtain an estimate of $\mathrm{V}_{\mathrm{s} \text {-Field }}$. The difference between lab and field $\mathrm{V}_{\mathrm{s}}$ values was about $10 \%$ (i.e., $\mathrm{V}_{\mathrm{s}-\mathrm{Lab}} / \mathrm{V}_{\mathrm{s} \text {-Field }}$ values were between 1.09 and 1.11), which indicates "medium to low" levels of sample disturbance using the Chiara and Stokoe criteria [23]. In this comparison, there are nuances to consider, such as the isotropic stress state in the laboratory differs from the anisotropic stress state of the soil in the field. However, the field $\mathrm{V}_{\mathrm{s}}$ values were estimated using a CPT-based correlation, so the comparison should be consider qualitative. A more comprehensive companion study by Beyzaei et al. (2015 and personnel communication) [24] and Stringer et al. [25] that focused on soil samples retrieved from the suburbs of Christchurch using the same sampling and testing procedures as this study also found good agreement between $\mathrm{V}_{\mathrm{s} \text {-Lab }}$ and $\mathrm{V}_{\mathrm{s} \text {-Field }}$ measurements in samples retrieved below the water table, where $\mathrm{V}_{\mathrm{s} \text {-Field }}$ was measured using direct-push cross-hole seismic testing (which was completed by the University of Texas at Austin research team led by K. Stokoe and B. Cox, personnel communication).

Cyclic triaxial (CTX) testing was carried out on retrieved DM test specimens using the CKC electropneumatic triaxial device [26]. Specimens were isotropically consolidated to conservative estimates of the field vertical effective stresses, which included estimates of geostatic overburden stresses, pore water pressure, and net pressure increases due to building loads. Stress-controlled CTX tests were performed using a sinusoidal loading pattern at a frequency of $0.1 \mathrm{~Hz}$. After the conclusion of cyclic testing, either a post-liquefaction volumetric reconsolidation test or a monotonic undrained shear strength test was performed.

\section{Buildings affected by shallow liquefaction}

\subsection{FTG-7 Building}

The FTG-7 building (S43.5263, E172.6384) was a 7-story 23.9-m high steel frame structure, which is $29.1 \mathrm{~m}$ wide (E-W) and $31.8 \mathrm{~m}$ long (N-S), supported on RC strip footings [26]. The foundation consists of 0.6-m thick RC perimeter strip footings embedded 1.2-m deep and widths of $2.4 \mathrm{~m}$ and $2.0 \mathrm{~m}$ in the N-S and E-W directions, respectively, and lengths of $29 \mathrm{~m}$ and $34 \mathrm{~m}$ in the N-S and E-W directions, respectively. Four interior N-S 0.6-m thick RC strip footings are embedded 0.6-m deep with a width of $3.3 \mathrm{~m}$ and a length of $25 \mathrm{~m}$.
The centerline distances between the N-S strip footings are between 5.5 and $6.3 \mathrm{~m}$. Strip footings are connected with each other with $0.6 \mathrm{~m}$ by $0.6 \mathrm{~m} \mathrm{RC}$ tie beams. The ground floor consist of $100-\mathrm{mm}$ thick unreinforced concrete slab and floors 2 through 7 consisted of 120$\mathrm{mm}$ thick RC slab over $0.75-\mathrm{mm}$ thick galvanized steel decking. The columns are wide-flange steel sections [27].

Minor liquefaction in the form of sand ejecta was observed 25-m northeast of the N-E corner of FTG-7 building after the 4 SEP 2010 Darfield earthquake (liquefaction descriptions are consistent with those presented in van Ballegooy et al. [6]). No significant building movements were noted. After the 22 FEB 2011 Christchurch earthquake, severe liquefaction was observed throughout the area, including along the side of the FTG-7 building. The S-E and S-W corners of the structure settled $100 \mathrm{~mm}$ and $70 \mathrm{~mm}$, respectively, relative to the structure's N-W corner. The structure settled differentially about $120 \mathrm{~mm}$ towards the S-E [4]. Minor liquefaction was observed in the vicinity of several of the exposed strip footings following the $13 \mathrm{JUN}$ 2011 earthquakes with additional differential settlement of $35 \mathrm{~mm}$ of the S-E corner of the structure relative to its N-W corner.

The site was originally characterized with $5 \mathrm{CPTs}$, which were located near each corner of the building and in the center of the northern perimeter of the building [26]. Three boreholes were then advanced near the southern corners of the building. The site shows fairly uniform soil conditions (Fig. 6). A surficial fill material with $\mathrm{D}_{\mathrm{r}}$ $\approx 60$ to $80 \%$ extends to a depth of $1-1.5 \mathrm{~m}$. The underlying sandy silt/ silty sand stratum, with variable $\mathrm{FC}$ and $\mathrm{I}_{\mathrm{c}}$ generally between $2.0-2.5$, extends to a depth of $7-8.5 \mathrm{~m}$. The "clean sand" equivalent relative density for this deposit varies between $35 \%$ and $55 \%$. The underlying medium dense sand stratum $\left(\mathrm{D}_{\mathrm{r}} \approx 55-70 \%\right.$ with $\left.\mathrm{I}_{\mathrm{c}} \approx 1.5-2.0\right)$ extends to a depth of around 14-16.5 m. This unit is underlain by a very dense sand unit $\left(D_{\mathrm{r}} \approx 90 \%\right)$ that is occasionally underlain by a $1-\mathrm{m}$ thick layer of clayey soil. The Riccarton Gravel was found at a depth of $19 \mathrm{~m}$. The water table depth was about $2 \mathrm{~m}$ throughout the earthquake sequence [10]..

In one of the three boreholes, the Gel-Push sampler was used to retrieve high quality samples and tested by Taylor et al. [28]. The remaining two boreholes were performed later and employed the DM sampler to retrieve high quality soil samples. Fig. 6 provides the location of these two boreholes (DM_Z1_BH1 and DM_Z1_BH2) that were located close to the S-E and S-W corners of the FTG-7 building footprint, respectively.

Fig. 7 provides the grain size distribution plots of triaxial specimens tested from the FTG-7 site. The upper part of the subsurface profile consists of silts and silty sands (ML and SM material), which is consistent with the CPT data provided in Fig. 6. Specimens tested from a depth of 10-11 m classified as sand to sand with silt (SP and SP-SM). Fig. 8 provides the results of a representative CTX test

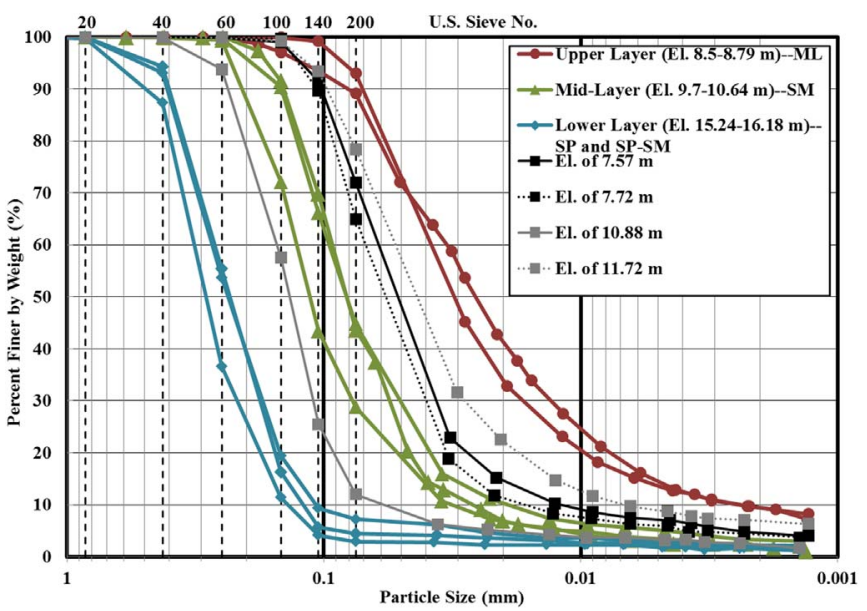

Fig. 7. Grain size distributions from soil samples at FTG-7 building site. 

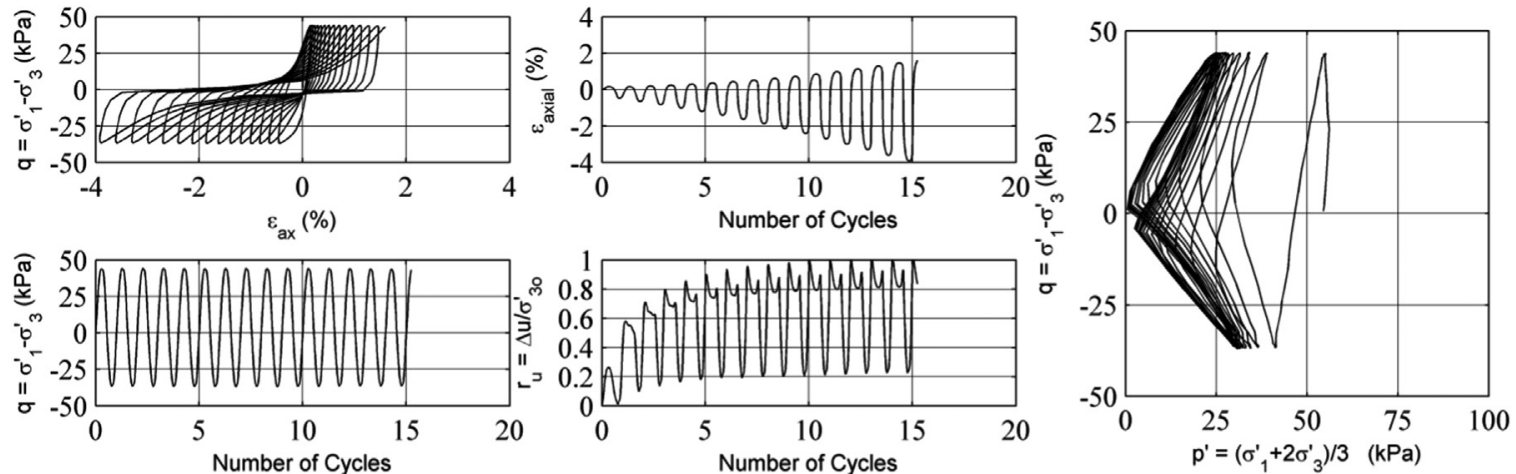

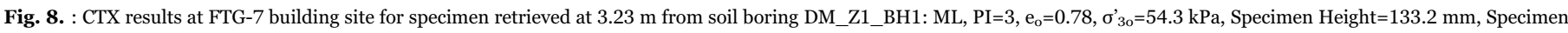
Diameter $=61.0 \mathrm{~mm}, \mathrm{G}_{\mathrm{s}}=2.68$, Load Frequency=0.1 Hz, CSR=0.371, $\mathrm{N}_{\mathrm{c}-3 \% \text { S.A. } \varepsilon a x}=13$.

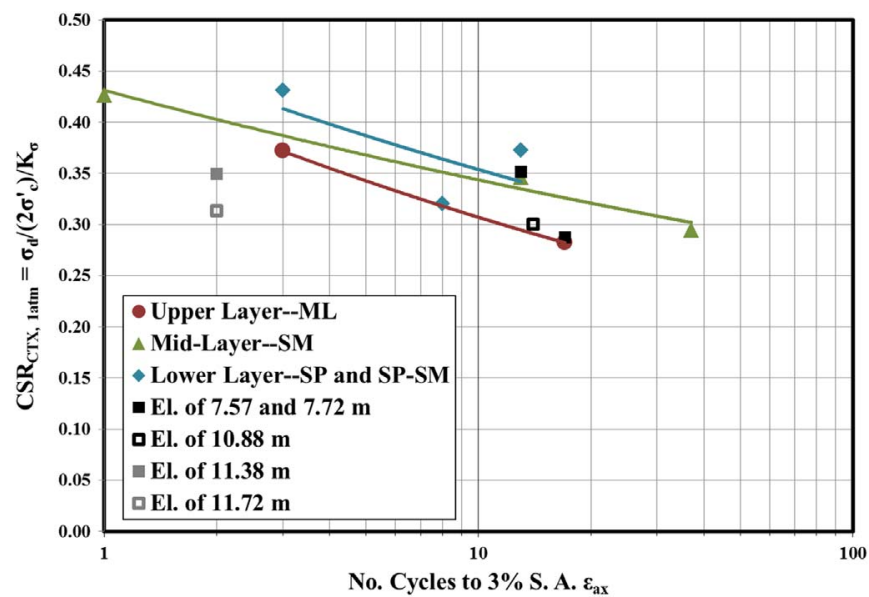

Fig. 9. Cyclic resistance from CTX tests performed on soil specimens from the FTG-7 building site.

performed on a specimen from the FTG-7 site. A strain-based liquefaction triggering criterion was used that was consistent with several previous studies (e.g., Bray and Sancio [16]). This criterion uses the number of cycles to $3 \%$ single amplitude axial strain, which typically occurred in extension. Fig. 9 provides a summary of applied cyclic stress ratio $\left(\mathrm{CSR}_{\mathrm{CTX}, 1 \mathrm{~atm}}\right)$ versus the number of cycles to $3 \%$ single amplitude axial strain $\left(\mathrm{N}_{\mathrm{c}-3 \%}\right.$ S.A. eax $)$ for CTX specimens tested from the FTG-7 site. CRR curves were interpreted by grouping tested specimens with similar grain size distributions and depths....

The upper finer silt material (depth of 3.5-3.79 m) was slightly weaker than the mid-depth coarser silty sand (depth of 4.7-5.64 m) below it (Fig. 9). The deeper sand (depth of 10.24-11.18 m) was slightly stronger than the mid-depth silty sand material (Fig. 9). Results from a few soil specimens from shallow and intermediate depths (2.57-6.72 m) were not entirely consistent with the interpreted CRR curves for their respective soil layers (Fig. 9). These soil specimens had slightly different grain size distributions (i.e., they were classified as silt and sand with silt; see Fig. 7). These soils generally plotted below or close to the CRR curve for the upper ML material, which indicates they were among the lowest strength materials at the site. Variability in natural soil deposits should be expected, and the variation in CRR from the lab tests are no more than one might expect based on the variation in grain size, potential variability in soil of a fluvial deposit, and the CPT results.

The results of these cyclic tests were used by Luque and Bray [29] to calibrate the PM4Sand soil constitutive model [30], which was used within the program FLAC 2D [31] to perform numerical analyses of the FTG-7 building during several of the Canterbury earthquakes. The results of their dynamic soil-structure-interaction analyses captured well the dynamic site response in this area of the CBD (the building was not instrumented with accelerometers so the calculated seismic site responses during the Canterbury earthquake sequence were compared with recorded ground surface earthquake motions [32]). The calculated liquefaction-induced differential settlement of the FTG-7 building during the Canterbury earthquake sequence also compared favorably with measured building settlements (Table 2). Calculated differential settlement of the FTG-7 building for the three primary events of the Canterbury earthquake sequence were $<10 \mathrm{~mm}, 20-30 \mathrm{~mm}$, and about $20 \mathrm{~mm}$ for the 4 SEP 2010, 22 FEB 2011 and 13 JUN 2011 earthquakes, respectively [29]. The corresponding measured differential settlements of the FTG-7 building were negligible, $10-30 \mathrm{~mm}$, and 0-20 mm for the 4 SEP 2010, 22 FEB 2011 and 13 JUN 2011 events, respectively.

\subsection{CTH auditorium}

The footprint of the auditorium structure of the CTH complex (S43.5269, E172.635) is approximately $63 \mathrm{~m}(\mathrm{E}-\mathrm{W})$ by $47 \mathrm{~m}$ (N-S) (Fig. 10; [27]). It consists of a basement, ground floor, gallery, and roof. Its foundation system is an outer ring of rectangular shallow RC spread footings that are $0.46-\mathrm{m}$ thick and either $2.2 \mathrm{~m}$ by $3.2 \mathrm{~m}$ or $3.15 \mathrm{~m}$ by $3.2 \mathrm{~m}$ in plan and an inner ring of square shallow $\mathrm{RC}$ spread footings that are $0.61-\mathrm{m}$ thick and $3.65 \mathrm{~m}$ by $3.65 \mathrm{~m}$ in plan. The base depths of the outer ring of footings are $3.6 \mathrm{~m}, 2.7 \mathrm{~m}$, or $1.9 \mathrm{~m}$ below the ground surface, and the base depths of the inner ring of footings are $3.8 \mathrm{~m}$ or $2.9 \mathrm{~m}$ below the ground surface. The outer footings are connected by RC tie beams that are $0.46-\mathrm{m}$ wide by $0.46-\mathrm{m}$ thick, and the inner footings are connected by $\mathrm{RC}$ tie beams that are $1.8 \mathrm{~m}$ wide and $0.61 \mathrm{~m}$ thick. Additionally, $0.91 \mathrm{~m}$ wide by $0.46 \mathrm{~m}$ thick strip footings support wall units around the outer ring at the corners. The thickness of the concrete basement slab is $200 \mathrm{~mm}$, and its base is $3.2 \mathrm{~m}$ below the ground surface. The ground floor slab is $100-130 \mathrm{~mm}$ thick, and the gallery flooring consists of either 0.13-m thick slab concrete or precast double tee units. The ground flooring above the basement and the gallery flooring are supported by RC beams and RC columns of varying dimensions. The roof is made up of mostly 75-100$\mathrm{mm}$ thick pre-cast concrete units that support a $50-\mathrm{mm}$ thick light-

Table 2

Measured and calculated differential settlements for the FTG-7 Building during the Canterbury Earthquake Sequence (from Luque and Bray [29]).

\begin{tabular}{lllll} 
Earthquake & $\mathrm{M}_{\mathrm{w}}$ & $\begin{array}{l}\text { Recorded } \\
\text { median PGA } \\
(\mathrm{g})\end{array}$ & $\begin{array}{l}\text { Measured } \\
\text { differential } \\
\text { settlements }(\mathrm{mm})\end{array}$ & $\begin{array}{l}\text { Calculated } \\
\text { differential } \\
\text { settlements (mm) }\end{array}$ \\
\hline 4 SEP 2010 & 7.1 & 0.20 & Negligible $^{\mathrm{a}}$ & $0-10$ \\
26 DEC 2010 & 4.8 & 0.21 & $\begin{array}{l}\text { Negligible } \\
\text { a }\end{array}$ & 0 \\
22 FEB 2011 & 6.2 & 0.44 & $10-30$ & $20-30$ \\
13 JUN 2011 & 6.0 & 0.21 & $0-20$ & 20 \\
\hline
\end{tabular}

${ }^{\mathrm{a}}$ Measurements were not taken because there was no significant damage. 

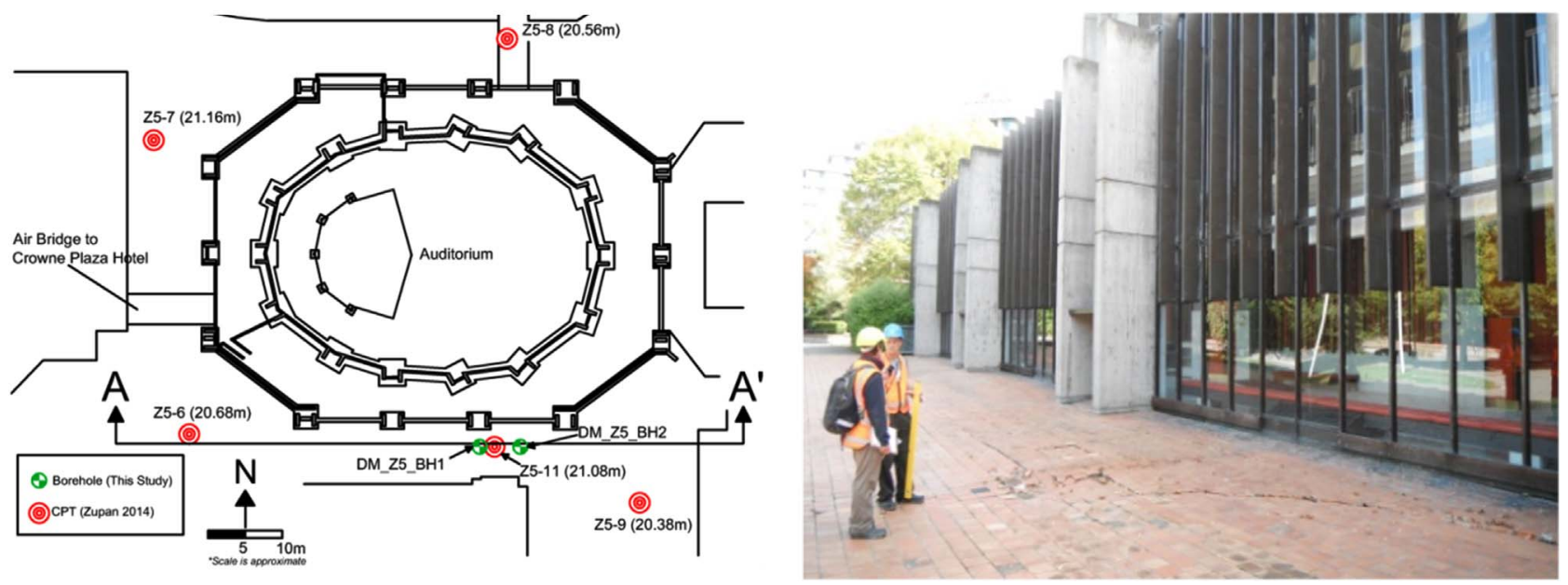

Fig. 10. CTH auditorium plan view (modified from Zupan [27]) and view of its southern side.

weight concrete topping. It is supported by the outer ring and inner ring RC columns. Struts provide additional support between the outer column ring and inner column ring, and a series of north-south trending trusses provide additional support across the span of the inner column ring..

The auditorium sustained severe structural damage during the 22 FEB 2011 Christchurch earthquake. Differential settlement of shallow foundations that supported the main load bearing columns of the structure led to angular distortion and subsequent damage to structural elements throughout the structure [27]. Moderate to severe levels of liquefaction-induced sediment ejecta were observed in many areas south of the auditorium, which is towards the Avon River. Only a minor amount of liquefaction-induced sediment ejecta was observed on the north side of the auditorium. At the south side of the auditorium, column settlements relative to the cracked concrete floor slab varied from $20 \mathrm{~mm}$ to $140 \mathrm{~mm}$. The cracked beam spanning the walkway at the south end of the auditorium was likely damaged by differential settlement of the inner column ring relative to the outer column ring with a measured angular distortion of $1 / 70$. Non-uniform settlements and distortions of the paving blocks were observed on the terrace to the south of the auditorium. Building settlements were measured after the 22 FEB 2011 Christchurch earthquake to be on the order of 300$500 \mathrm{~mm}$ [27]. As there were no reports of liquefaction following the 4 SEP 2010 Darfield earthquake, these measured building movements are assumed to be largely a result of the Christchurch earthquake. Minor liquefaction was observed after the 13 JUN 2011 event without significant settlement.

The factor of safety for liquefaction triggering $\left(\mathrm{FS}_{\mathrm{l}}\right)$ was calculated using the Robertson and Wride procedure [33] using median PGA values from Bradley and Hughes [13]. Based on the CPT data provided by Zupan [27], as shown in Fig. 11, a shallow layer of silty sand and silt $\left(\mathrm{I}_{\mathrm{c}}\right.$ is $\left.1.75-2.6\right)$ is underlain by a layer of gravelly and sandy material $\left(\mathrm{I}_{\mathrm{c}}\right.$ from 1 to 1.7), which is underlain by a layer of clean to slightly silty sand $\left(I_{c}<2.05\right)$. The shallow silty sand and silt layer and deeper clean to slightly silty sand layer generally had $\mathrm{FS}_{l}<1$ for the Christchurch earthquake level of shaking [27]. The intermediate depth gravelly and sandy soil $(z=5-12 \mathrm{~m})$ was dense and had $\mathrm{FS}_{l}>1$. Retrieved soil samples indicate that the upper part of the shallow soil layer is ML (to a depth of just under $4 \mathrm{~m}$ ), which overlies a layer of SP-SM material (to a depth of about $4.5 \mathrm{~m}$ ). Fig. 12 shows the grain size distribution plots for the CTX test specimens that were obtained at the CTH site (see Fig. 11 for sample depths)...

The Zhang et al. [33] procedure was applied to the five CPTs shown in Fig. 10 to estimate free-field, level ground settlements due to postliquefaction volumetric strains by Zupan [27]. The 1D liquefactioninduced ground settlement were calculated to be $70-220 \mathrm{~mm}$ for the
22 FEB 2011 Christchurch earthquake [27]; whereas as mentioned previously, the measured settlement were $300-500 \mathrm{~mm}$. Although negligible settlements were observed following the 4 SEP 2010 Darfield earthquake, the 1D CPT-based procedure [34] calculated liquefaction-induced ground settlement of $50-170 \mathrm{~mm}$ for the median PGA estimated by Bradley and Hughes [13], which is not much less than the range of ground settlement calculated for the 22 FEB 2011 Christchurch earthquake (i.e., $70-220 \mathrm{~mm}$ ). Therefore, building settlements were underestimated for the Christchurch earthquake and overestimated for the Darfield earthquake.

Two boreholes were drilled along the southern side of the main auditorium building at the CTH site to obtain DM samples of the critical soil layers (Figs. 10 and 11). Three CTX tests were conducted on the upper silt (specimen depths of 3.0-3.74 m), 2 CTX tests were conducted on the upper silty sand (specimen depths of 4.2-4.5 m), and 4 CTX tests were conducted on the deeper silty sand material (specimen depths of $14.2-15.6 \mathrm{~m}$ ). Fig. 13 provides a summary of applied cyclic stress ratio $\left(\mathrm{CSR}_{\mathrm{CTX}, 1 \mathrm{~atm}}\right)$ versus the number of cycles to $3 \%$ single amplitude axial strain $\left(\mathrm{N}_{\mathrm{c}-3 \%}\right.$ s.A. eax $)$ for all CTX specimens tested from the CTH site. The interpreted cyclic resistance ratio (CRR) curves for these tests indicate that the upper silt is the weakest of the three layers studied, followed by the upper SP-SM material. The deeper silty sand represents the strongest of the material tested. This trend of the upper portion of the subsurface consisting of a slightly weaker, finer material overlying a stronger coarser material was observed at other CBD sites..

\subsection{CTUC building}

The CTUC building (S43.5286 E172.6425) was approximately $20 \mathrm{~m}$ west of the Armagh-Madras parking lot discussed previously. It was a six-story RC frame structure with RC core walls and block in-fill walls with its roof supported by steel framing. The structure was largely supported on shallow footings interconnected with tie beams The CTUC building and its performance during the Canterbury earthquake sequence is described in detail in Bray et al. [4]. Only additional insights from recent CTX testing and some of the previously noted key observations are described herein.

Severe liquefaction of the foundation soils during the 22 FEB 2011 Christchurch earthquake induced significant total and differential settlements of the building, leading to structural distortions and cracking [1]. The building tilted to the east 0.4-0.5 degrees. Differential settlement of the southeast corner of the building produced most of the structural damage. Several of the beams on the south side of the building were cracked near the beam-column connections. The building settled more on its south side than on its north side and more 


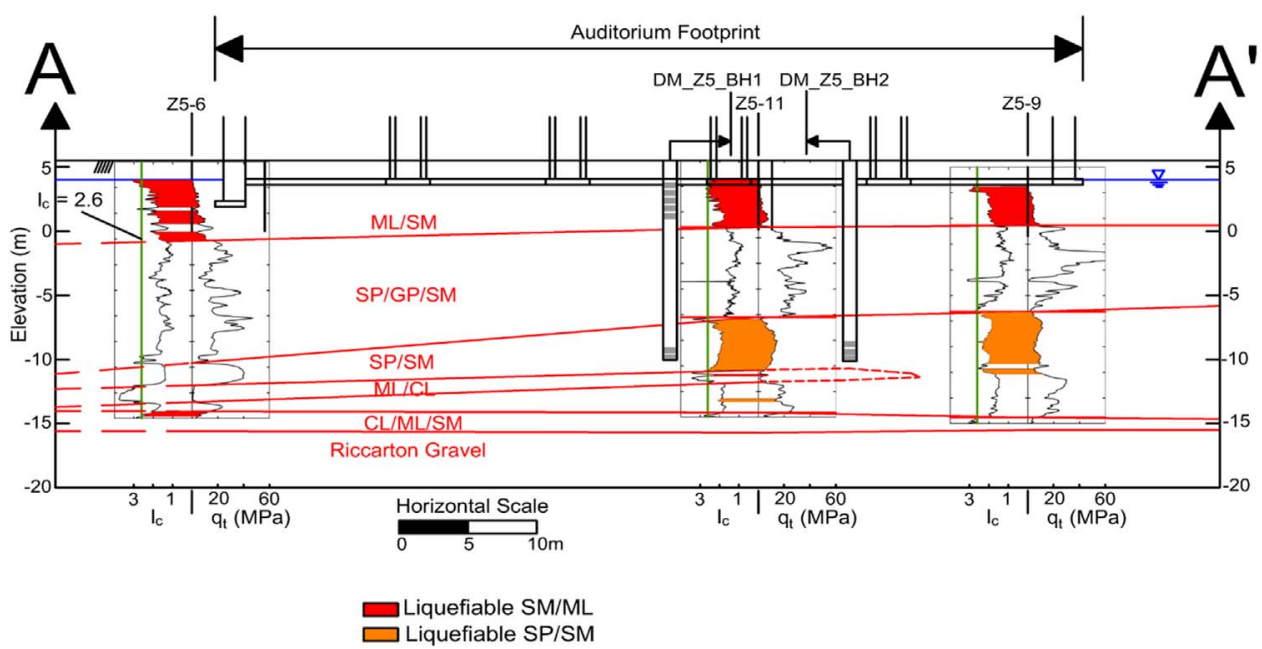

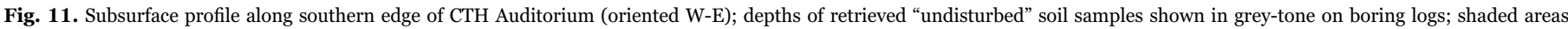

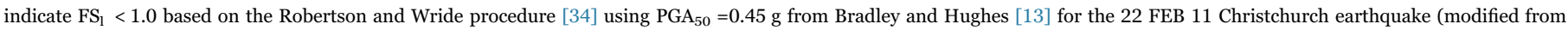
Zupan [27]).

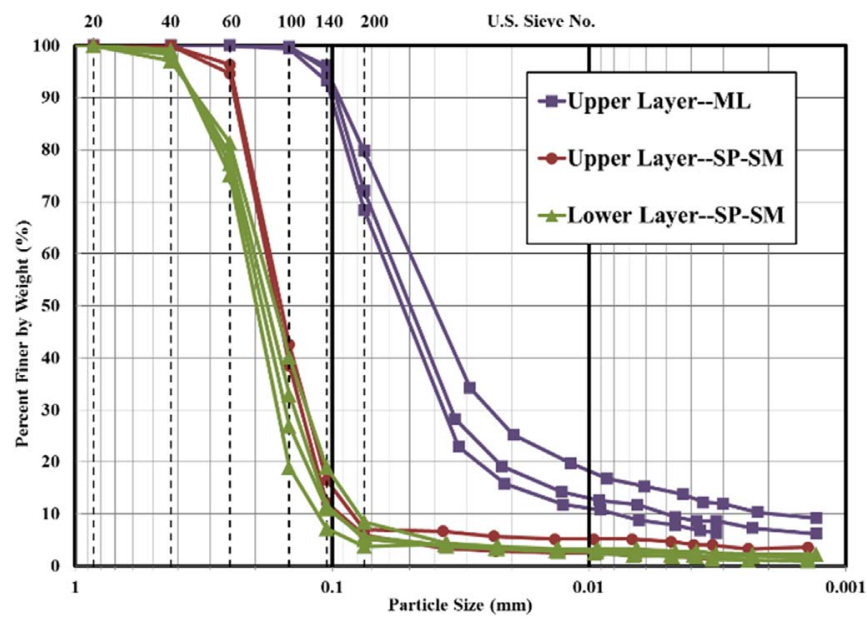

Fig. 12. Grain size distributions from soil samples at CTH building site.

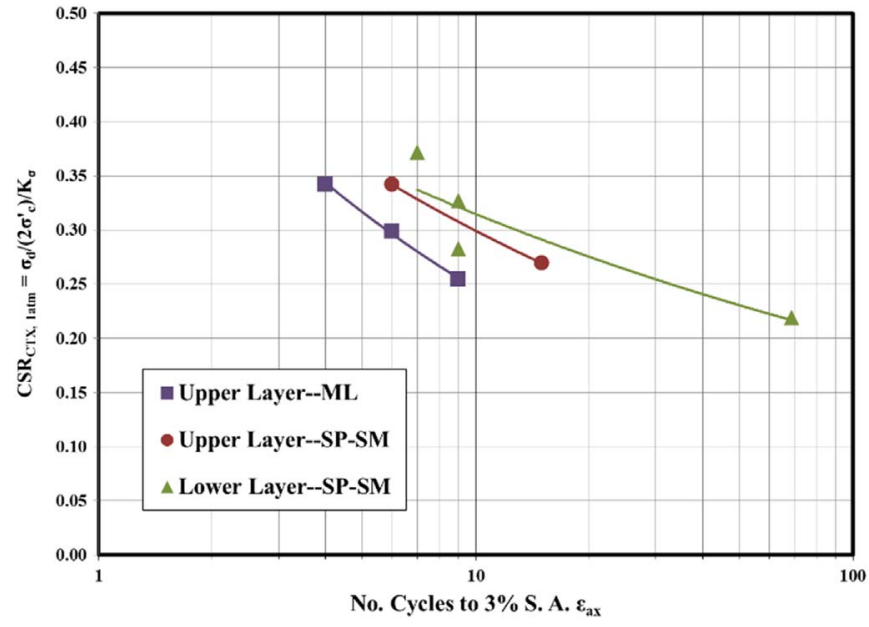

Fig. 13. Cyclic resistance from CTX tests performed on soil specimens from the CTH building site.

on its east side than its west side. Approximately $200 \mathrm{~mm}$ of the $250 \mathrm{~mm}$ of differential building settlement along the eastern side of the building was measured across its two southernmost spans (angular distortion $\approx 1 / 50$ ), which is consistent with the observed cracking of structural beams. Damage to the building was negligible during the other Canterbury earthquakes.

Six CPTs and one exploratory boring were performed at the CTUC building site. The generalized subsurface conditions along the east side of the CTUC building are depicted in Fig. 14. The groundwater depth was estimated to be $2.5 \mathrm{~m}$ for the 4 SEP 2010, 26 DEC 2010, and 22 FEB 2011 earthquakes, and $2.0 \mathrm{~m}$ for the 13 JUN 2011 earthquake based on NZGD [10]. The shallow SM/ML layer observed at CPT Z4-5, which is at the southeast corner of the building to a depth of 4-5 m, is similar to the upper unit described previously at the nearby ArmaghMadras parking lot. It had $\mathrm{q}_{\mathrm{t}}<3 \mathrm{MPa}, 2<\mathrm{I}_{\mathrm{c}}<2.5$, and thus was likely to liquefy under strong ground shaking. The shallow SM/ML unit was not observed below the groundwater table at and north of CPT Z4-28 near the center of the east side of the building..

There are liquefiable soils at each of the CPT locations depicted in Fig. 14. However, the distinguishing difference between them are the shallow liquefiable soils just beneath the building foundation at CPT Z4-5 whereas the liquefiable soils at CPTs Z4-28, Z4-7 and Z4-10 are located primarily at depths below $8 \mathrm{~m}$. The dramatic change in the shallow soil conditions from the building's north end, which did not contain shallow liquefiable soils, to its south end, which contained shallow liquefiable soils, led to significant differential settlement over the southernmost spans of the building frame. The buried shallow SM/ ML deposit that produced the well-defined liquefaction feature in the nearby Armagh-Madras parking lot just cut across the southeast corner of the CTUC Building and caused much of the observed damage.

Low $\mathrm{FS}_{1}$ values were calculated in the shallow SM/ML layer for the 22 FEB 2011 Christchurch earthquake [4]. $\mathrm{FS}_{1}$ values just below one are also calculated for the 4 SEP 2010 Darfield and 13 JUN 2011 earthquakes. Although there were no reports of liquefaction at this location after these events, it is possible that a minor amount of liquefaction was unreported or that marginal liquefaction occurred and surface manifestations were not observed. It is also possible that liquefaction triggering procedures employed underestimated the $\mathrm{FS}_{1}$ at this site for these events.

The post-liquefaction residual shear strength of the shallow SM/ML layer was estimated to be $6-10 \mathrm{kPa}$ using the Olson and Stark [35] and Idriss and Boulanger [36] procedures. The static FS against a bearing capacity failure based on a two-layer cohesive soil deposit solution provided in the NAVFAC Design Manual 7.02 [37] is 2.1-2.3 at the location of the southeast corner footing, using the residual shear strength of the shallow liquefiable SM/ML materials and an equivalent undrained shear strength of the SM/ML materials above the groundwater. If the materials above the groundwater lost strength due to the upward migration of liquefied soil, then the FS is below one. The 


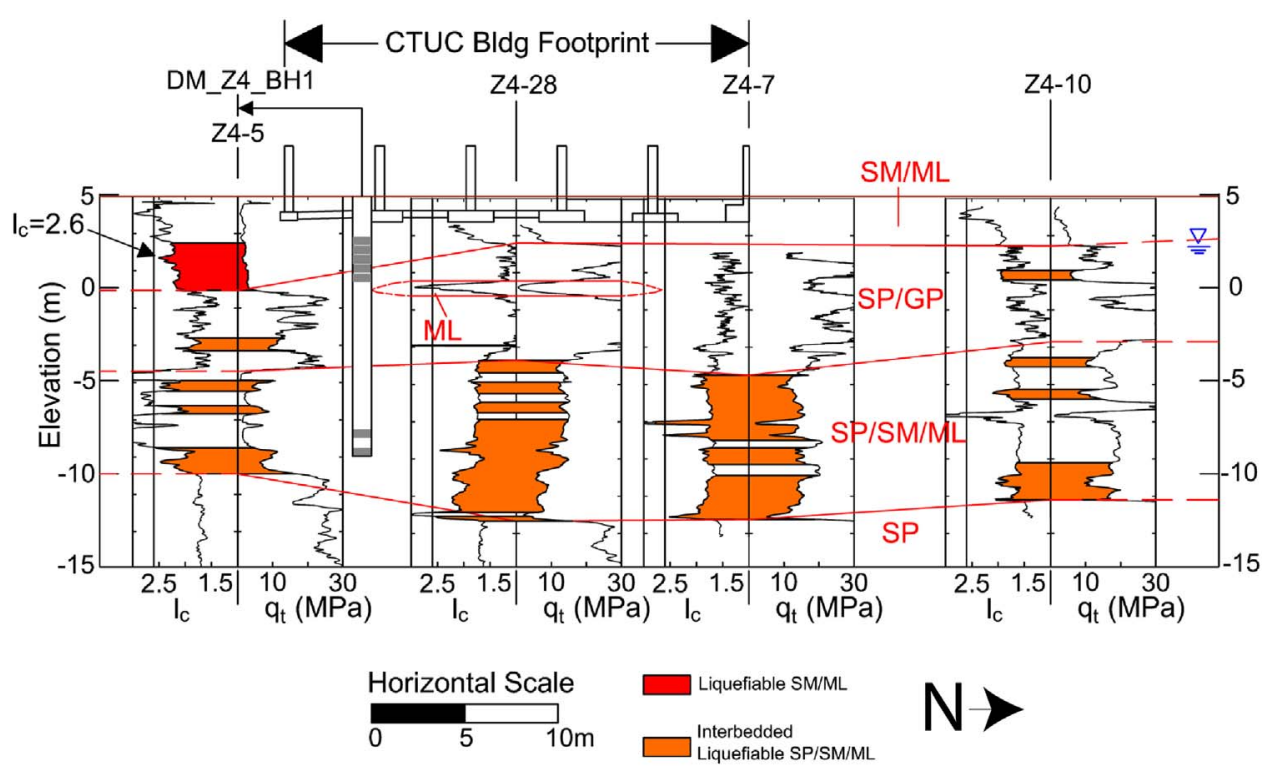

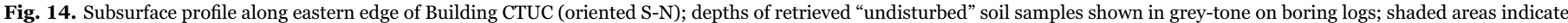

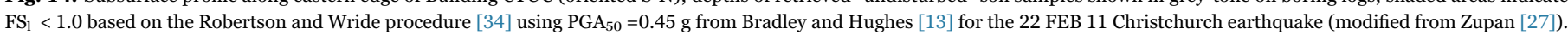

southeast footing may have undergone a partial bearing capacity failure, but its differential settlement was largely the result of ground loss due to sediment ejecta, which was observed at the site [4], and due to some contribution of the other settlement mechanisms described by Bray and Dashti [38], because bulging of the ground surface was not observed at this site. Conventional 1D liquefaction-induced ground settlement procedures, which do not capture important shear-induced deformation mechanisms, such as SSI ratcheting and partial bearing failure, and the effects of ground loss due to sediment ejecta, underestimated the differential settlement measured after the 22 FEB 2011 Christchurch earthquake. The calculated 1D liquefaction-induced ground settlements at CPTs Z4-5, Z4-28, and Z4-17 (i.e., from south to north along the eastern side of the CTUC building using Robertson and Wride [34] and Zhang et al. [33]) were $160 \mathrm{~mm}, 160 \mathrm{~mm}$, and $100 \mathrm{~mm}$, respectively [4]. Thus, the calculated differential settlement was only $60 \mathrm{~mm}$, whereas the measured differential settlement was $250 \mathrm{~mm}$ [4]. Conversely, 1D procedures overestimated the differential ground settlement observed after the 4 SEP 2010 Darfield and 13 JUN 2011 earthquakes $[4,5]$.

A borehole was drilled in the southeast corner of the CTUC building site to obtain high quality samples of soils in the area where the largest building settlement occurred (Fig. 14). Three samples were obtained of the upper liquefiable layer (depth of 2.75-4.05 m) and one sample of the lower sand was obtained (at a depth of $13.67 \mathrm{~m}$ ). Index testing on the test specimens revealed that the upper layer of silty soil comprises a layer of silty sand (SM) from a depth of $2.75-3.40 \mathrm{~m}$ and a layer of sand and sand with silt (SP and SP-SM) from a depth of 3.41-4.05 m. The grain size distributions of the retrieved soils are shown in Fig. 15. A summary of the applied stress normalized cyclic stress ratio $\left(\mathrm{CSR}_{\mathrm{CTX}, 1 \mathrm{~atm}}\right)$ versus the number of cycles to $3 \%$ single amplitude axial strain $\left(\mathrm{N}_{\mathrm{c}-3 \%}\right.$ S.A. eax $)$ for CTX specimens tested from the CTUC site is shown in Fig. 16. The resulting cyclic resistance ratio (CRR) curves indicate that the finer sub-layer of SM material is slightly weaker than the coarser SP and SP-SM material...

One of the key findings of the CTX testing is the presence of two distinct layers of soil that have slightly different liquefaction resistances in the upper critical layer of soil in the SE corner of the site. This was not as clearly evident based on the CPT results (i.e., the $\mathrm{q}_{t}$ and $\mathrm{I}_{\mathrm{c}}$ profiles shown in Fig. 14 are relatively uniform for the upper layer of liquefiable material). The laboratory testing results coupled with the CPT interpretations provide data and insights for researchers investigating the seismic performance of the CTUC building during the

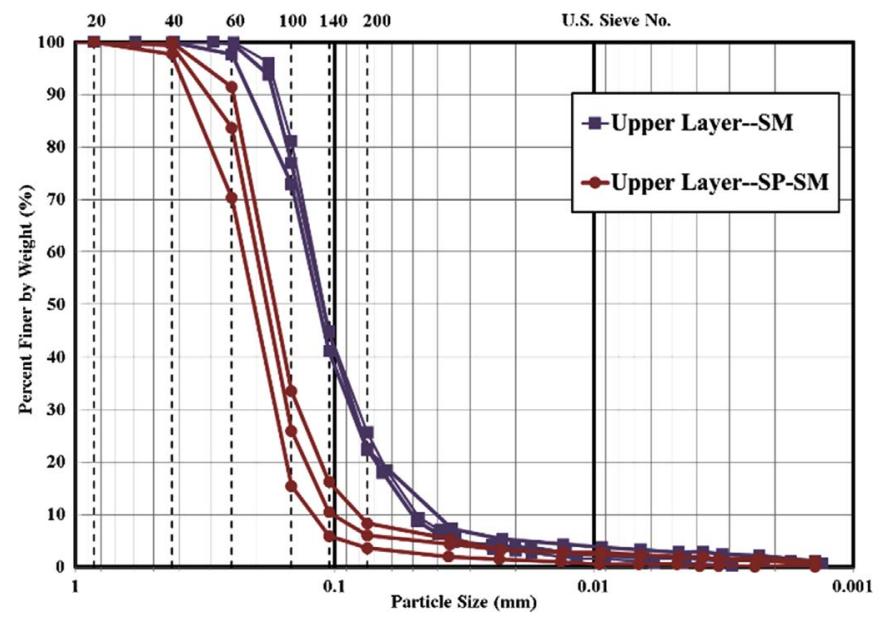

Fig. 15. Grain size distributions from soil samples at CTUC building site.

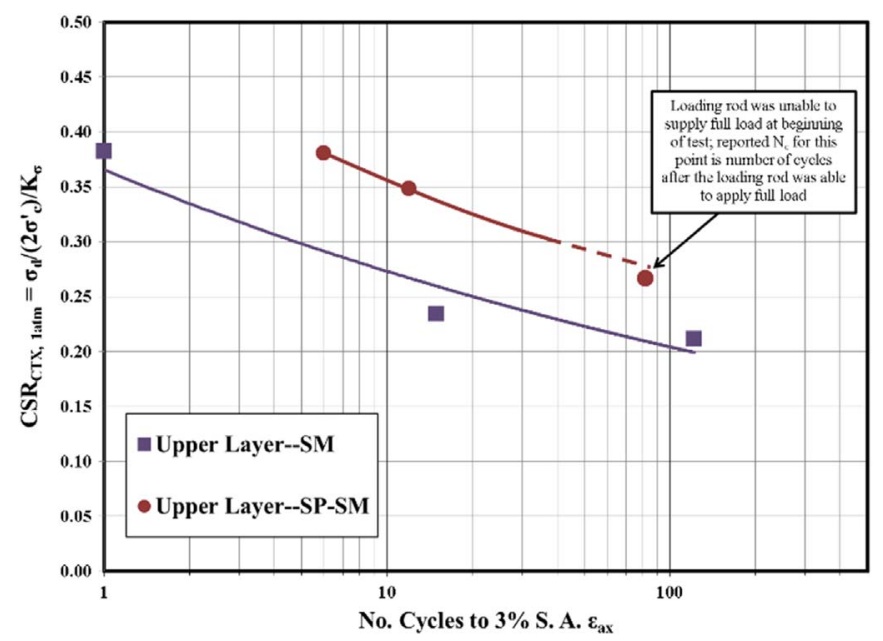

Fig. 16. Cyclic resistance from CTX tests performed on soil specimens from the CTUC building site in upper silty sand unit. 
Canterbury earthquakes.

\section{Conclusions}

Liquefaction of loose shallow sand and silt layers led to much damage in the CBD during the Canterbury earthquake sequence, especially in areas with significant ejecta $[1,4]$. The CPT proved to be a useful site characterization tool in Christchurch. Its results enabled liquefaction triggering evaluations using established simplified procedures that were generally conservative. Severe liquefaction was estimated in areas along the Avon River in the CBD for the 22 FEB 2011 Christchurch earthquake, which is consistent with the observations, but liquefaction triggering was also estimated at CBD sites that did not manifest liquefaction for the 4 SEP 2010 Darfield and 13 JUN 2011 earthquakes [4]. The overestimation of liquefaction triggering for these events led to $1 \mathrm{D}$ post-liquefaction ground settlement estimates that were generally similar to those estimated for the 22 FEB 2011 Christchurch earthquake, whereas significant building settlements and damage in the CBD were observed only for the 22 FEB 2011 Christchurch earthquake and not for the 4 SEP 2010 Darfield and 13 JUN 2011 earthquakes [4]. Thus, while the CPT-based liquefaction procedures provide valuable insights, analyses presented in Bray et al. [4] showed it was difficult to capture the actual range of ground and building performances in the CBD observed after each of the key events of the Canterbury earthquake sequence.

Simplified 1D post-liquefaction reconsolidation ground settlement procedures do not capture important shear-induced deformation mechanisms and the effects of ground loss due to sediment ejecta [38]. Performance-based earthquake engineering requires improved analytical procedures to discern between the differing levels of performance observed in Christchurch during the Canterbury earthquake sequence [4]. Two dimensional (2D) nonlinear effective stress analyses can capture shear-induced deformation mechanisms in addition to volumetric-induced settlement mechanisms [29,38]. However, robust soil constitutive models are required. Given the brittle nature of the liquefaction phenomenon as soil transforms rapidly from a stiff to a soft response as the excess pore water pressure rises beyond a threshold value, the development of robust analytical procedures to evaluate the effects of liquefaction on buildings will be challenging. However, the Christchurch CBD case histories provide a comprehensive set of ground and building performance data for developing these procedures.

The Dames and Moore hydraulic fixed piston sampler with thinwall brass tubes was shown to retrieve high quality samples of silts and silty sands and medium dense sands. It could not retrieve undisturbed samples of loose clean sands. Loose clean sands were most likely densified during the sampling and specimen preparation procedures prior to testing. However, reasonable trends were observed with regards to the liquefaction resistance of medium dense sands, silts, and silty sands. The data provided by the advanced laboratory testing of these soils is important for performing nonlinear effective stress analyses, whose constitutive models can be calibrated using the CTX test results.

The seismic performances of most of the office buildings in the CBD that were investigated in this study were dictated by a shallow layer of silty sand or sandy silt that liquefied. The shallow liquefiable SM/ML layer, when present within the soil profile, was often the critical layer in the observed liquefaction in the CBD. Its thickness below the groundwater table could vary considerably over relatively short distances. When this layer was present and supported shallow foundations, the seismic performance of the structure was affected greatly by the vertical deformation of the shallow liquefiable soil layer. The potential for poor structural performance due to liquefaction directly beneath shallow foundations cannot be overemphasized.

\section{General recommendations}

The CPT is useful in subsurface characterization and as a basis for evaluating liquefaction triggering. The design of shallow foundations for multi-story buildings at sites with liquefiable soils should be carried out with caution. If liquefaction-induced settlements are judged to be excessive, deep foundations or ground improvement is required. However, at present, there are no reliable methods for estimating liquefaction-induced building settlements. Additionally, for those cases wherein the structure already exists at a site not previously well characterized or at a site wherein a recent study has significantly increased the seismic hazard, a reliable approach to evaluating the seismic performance of the structure is required.

Advanced numerical analyses supported by cyclic testing of carefully retrieved high quality soil specimens can provide important insights in addition to those provided by simplified procedures based solely on CPT data. Dynamic finite difference or finite element analyses performed with calibrated, robust nonlinear effective stress analyses can provide an enhanced level of understanding of the cyclic response of the key soil deposits and their potential effects on the overlying structure $[29,38]$.

Shallow foundations at sites with a shallow liquefiable layer can undergo shear-induced ground settlement as well as settlement due to the removal of soil from beneath foundation elements through sediment ejecta [38]. These mechanisms are not captured and hence cannot be estimated using only 1D post-liquefaction volumetric reconsolidation procedures. The $1 \mathrm{D}$ procedures are applicable for level-ground sites with no influence of the overlying structure. Therefore, 1D procedures should not be relied upon solely for evaluating the seismic performance of shallow foundations at potentially liquefiable sites.

Based on the results of this study and previous studies of liquefaction-induced building settlement, general interim recommendations are provided. The engineer should gain insight through a series of analyses and considerations as follows:

1. Perform liquefaction triggering assessment and calculate $1 \mathrm{D}$ postliquefaction reconsolidation settlements (e.g., using the Zhang et al. procedure [33]).

2. Estimate the likelihood of sediment ejecta developing at the site by using ground failure indices such as LSN [6], LPI [39], or the Ishihara ground failure design chart [40]. If the amount of sediment ejecta is significant, estimate the amount of foundation settlement as a direct result of loss of ground due to the formation of sediment ejecta. This can best be done using relevant case histories to estimate the amount of ejecta and then assuming that the ejecta has been removed below the building foundation.

3. Perform conventional and pseudostatic bearing capacity analyses using post-liquefaction strengths of liquefied soils [e.g., using procedures presented in NAVFAC DM 7.02 [37]). If the postliquefaction conventional bearing capacity FS is less than about 1.5 for light to medium size buildings or the post-liquefaction pseudostatic bearing capacity FS is less than about 2 for heavy or tall buildings, large movements are possible, and the potential seismic building performance can generally be judged to be unsatisfactory.

4. Perform nonlinear effective stress analyses to estimate building movements that includes shear-induced deformation. Such analyses require good characterization of the earthquake shaking and the cyclic response of key soil strata.

5. Use engineering judgment. Through identification of the key mechanisms of liquefaction-induced building movement (e.g., see Bray and Dashti [38]), simplified and advanced analyses can be used to provide valid insights. However, case histories and judgment are equally important to consider. Importantly, the potentially effects of shear-induced deformations and sediment ejecta should be consid- 
ered.

\section{Acknowledgments}

The primary support for the US researchers was provided by grants from the U.S. National Science Foundation (NSF) through CMMI1332501, CMMI-1306261, and CMMI-1137977 and the U.S. Geological Survey through G12AP20034. The primary support for the NZ researchers was provided by the Earthquake Commission New Zealand (EQC) and University of Canterbury. Any opinions, findings, and conclusions or recommendations expressed in this material are those of the authors and do not necessarily reflect the views of the EQC, NSF, or USGS. We would also like to acknowledge the assistance of all NZ and US GEER team members who participated in the reconnaissance of these events, as well as those who participated in the UCB-UC follow-on research, including Josh Zupan, Roberto Luque, Christine Beyzaei, Mark Stringer, Michael Riemer, Merrick Taylor, Tom O’Rourke, Brendon Bradley, Russell Green, and several others. Site explorations were performed with partial support by Iain Haycock, Nathan Barnes, Richard Wise, and Mike Pickworth of McMillan Drilling Services and Simon Faulkner and John Cresswell of Fugro BTW. Sjoerd Van Ballegooy and Mike Jacka of Tonkin \& Taylor shared useful data and insights. ENGEO performed a majority of the soil index tests through cost-sharing. Rick Wentz of Paragon Geotechnical, Ian McCahon of Geotech Consulting Ltd., and Nick Traylen shared useful data and insights as well.

\section{References}

[1] Cubrinovski M, Bray JD, Taylor M, Giorgini S, Bradley BA, Wotherspoon L, Zupan J. Soil liquefaction effects in the Central Business District during the February 2011 Christchurch Earthquake. Seismol Res Lett 2011;82:893-904.

[2] Cubrinovski M, Bradley B, Wotherspoon L, Green R, Bray J, Wood C, Pender M, Allen J, Bradshaw A, Rix G, Taylor M, Robinson K, Henderson D, Giorgini S, Ma K, Winkley A, Zupan J, O'Rourke T, DePascale G, Wells D. Geotechnical aspects of the 22 February 2011 Christchurch Earthquake. Bulletin of the New Zealand. Soc Earthq Eng 2011;44(4):205-26.

[3] M. Cubrinovski, R.A. Green, L. Wotherspoon [Eds]. Geotechnical reconnaissance of the 2011 Christchurch Earthquake. Technical Report, doi:10.18118/G68G65, 2011

[4] Bray JD, Cubrinovski M, Zupan J, Taylor M. Liquefaction effects on buildings in the Central Business District of Christchurch. Earthquake Spectra J 2014;30.

[5] J.D. Bray, M. Cubrinovski, J. Zupan, M. Taylor, CPT-based liquefaction assessments in Christchurch, New Zealand, CPT'14: Proceedings of the Third International Symposium on Cone Penetration Testing, Las Vegas, NV, May 13-14, 2014

[6] van Ballegooy S, Malan P, Lacrosse V, Jacka ME, Cubrinovski M, Bray JD, O'Rourke TD, Crawford SA, Cowan H. Assessment of Liquefaction-Induced Land Damage for Residential Christchurch. Earthquake Spectra J 2014;30.

[7] Brown LJ, Weeber JH. Geology of the Christchurch Urban Area. Lower Hutt, New Zealand: Institute of Geological and Nuclear Sciences; 1992.

[8] Brown LJ, Beetham RD, Paterson BR, Weeber JH. Geology of Christchurch, New Zealand. Environ Eng Geosci 1995;1(4):427-88.

[9] Tonkin + Taylor. Christchurch Central City Geological Interpretive Report report prepared for the Christchurch City Council, Dec. 2011 (Ver. 1.1); 2011.

[10] New Zealand Geotechnical Database 2016. Funded by the Ministry of Business Innovation and Employment and the Earthquake Commission, New Zealand. Accessible at: 〈https://www.nzgd.org.nz/〉.

[11] Sancio RB, Bray JD. An Assessment of the effect of rod length on SPT energy calculations based on measured field data. Geotech Test J ASTM 2005;28(1):1-9.

[12] Wotherspoon LM, Orense RP, Green RA, Bradley BA, Cox BR, Wood CM. Assessment of liquefaction evaluation procedures and severity index frameworks at Christchurch strong motion stations. Soil Dyn Earthq Eng 2015;79:335-46.

[13] B.A. Bradley, M. Hughes, Conditional Peak Ground Accelerations in the Canterbury Earthquakes for Conventional Liquefaction Assessment. Technical Report Prepared for the Department of Building and Housing; 2012.

[14] Yoshimi Y, Hatanaka M, Oh-Oka H. Undisturbed sampling of saturated sands by freezing Soils Found Jpn Soc Soil Mech Found Eng 1978;18(3):59-73.

[15] Yoshimi Y, Tokimatsu K, Ohara J. In situ liquefaction resistance of clean sands over a wide density range. Geotechnique 1994;44(3):479-94.

[16] Bray JD, Sancio RB. Assessment of the liquefaction susceptibility of fine-grained soils. J Geotech Geoenviron Eng, ASCE 2006;132(9):1165-77.

[17] M.L Taylor, M. Cubrinovski, I. Haycock, Application of new 'Gel push' sampling procedure to obtain high quality laboratory test data for advanced geotechnical analyses. 2012 New Zealand Society for Earthquake Engineering Conference. Christchurch, New Zealand, NZSEE; 2012.

[18] M.J. Hvorslev, Subsurface exploration and sampling of soils for civil engineering purposes. Waterways Experiment Station, Vicksburg, Miss; 1949.

[19] Salgado R, Mitchell J, Jamiolkowski M. Cavity expansion and penetration resistance of sand. J Geotech Geoenviron Eng 1997;123(4):344-54.

[20] M. Jamiolkowski, D. Lo Presti, M. Manaserro, Evaluation of the relative density and shear strength of sands from CPT and DMT. Soil Behavior and Soft Ground Construction, GSP 119, pp. 201-238, Reston, Virginia. ASCE. via Mayne, P. W. 2014. Interpretation of geotechnical parameters from seismic piezocone tests. CPT 2014. Paper No. KN-2; 2001

[21] Boulanger RW, Idriss IM. CPT and SPT based liquefaction triggering procedures. Report No. UCD/CGM-14/01. Davis, CA: University of California; 2014. p. 134.

[22] McGann C, Bradley B, Taylor M, Wotherspoon L, Cubrinovski M. Development of an empirical correlation for predicting shear wave velocity of Christchurch soils from cone penetration test data. Soil Dyn Earthq Eng 2014:15-27.

[23] N. Chiara, K. H. II. Stokoe, Sample disturbance in resonant column test measurement of small-strain shear wave velocity. Soil Stress-Strain Behavior: Measurement, Modeling and Analysis Geotechnical Symposium. Roma, 2006. Ling H.I. et al. (eds.), pp. 605-613.

[24] C.Z. Beyzaei, J.D. Bray, M.C. Cubrinovski, M.E. Riemer Stringer, M.E. Jacka, R. Wentz, Liquefaction resistance of silty soils at the Riccarton Road site, Christchurch, New Zealand. In: Proceedings of the 6th International Conference on Earthquake Geotechnical Engineering, 6ICEGE, 1-4 November, Christchurch, New Zealand; 2015

[25] M.E Stringer, C.Z. Beyzaei, M.C. Cubrinovski, J.D. Bray, M. Riemer, M.E Jacka, R Wentz, Liquefaction characteristics of Christchurch silty soils: Gainsborough Reserve. In: Proceedings of the 6th International Conference on Earthquake Geotechnical Engineering, 6ICEGE, 1-4 November, Christchurch, New Zealand; 2015

[26] Li XS, Chan CK, Shen CK. An automated triaxial testing systemAdvanced Triaxial Testing of Soil and Rock. Philadelphia: American Society for Testing and Materials: 1988. p. 95-106.

[27] Zupan J. Seismic performance of buildings subjected to soil liquefaction $[\mathrm{PhD}$ Thesis]. Berkeley: University of California; 2014.

[28] Taylor M, Cubrinovski M, Bradley B. Characterisation of ground conditions in the Christchurch central business district. Aust Geomech J 2012;47(4):43-58.

[29] R. Luque, J.D. Bray, Dynamic analysis of a shallow-founded building in Christchurch during the Cantebury earthquake sequence. In: Proceedings of the 6th International Conference on Earthquake Geotechnical Engineering, 6ICEGE, 1-4 November, Christchurch, New Zealand; 2015

[30] Boulanger RW, Ziotopoulou K. PM4Sand (Version 2): a sand plasticity model for earthquake engineering applications. Report no. UCD/CGM-12/01, center for Geotechnical Modeling. Davis, CA: Department of Civil and Environmental Engineering, University of California; 2012. p. 100.

[31] Itasca . Flac - fast Lagrangian analysis of Continua, Version 6.0. Minneapolis, Minnestota: Itasca Consulting Group, Inc.; 2009.

[32] Markham CS, Bray JD, Macedo J, Luque R. Evaluating nonlinear effective stress site response analyses using records from the Canterbury Earthquake Sequence. Soil Dyn Earthq Eng J 2016;82(1):84-98.

[33] Zhang G, Robertson PK, Brachman RWI. Estimating liquefaction-induced ground settlements from CPT for level ground. Can Geotech J 2002;39:1168-80.

[34] Robertson PK, Wride CE. Evaluating cyclic liquefaction potential using the cone penetration test. Can Geotech J 1998;35:442-59.

[35] Olson SM, Stark TD. Liquefied strength ratio from liquefaction flow failure case histories. Can Geotech J 2002;39:629-47.

[36] Idriss IM, Boulanger RS. Soil liquefaction during earthquakes. Oakland, CA: Earthquake Engineering Research Institute; 2008

[37] NAVFAC . DM-7.02, Foundations and earth Structures. Alexandria. VA: U.S.: Department of Navy, Naval Facilities Engineering Command; 1986.

[38] Bray JD, Dashti S. Liquefaction-induced building movements. Bulletin of Earthquake Engineering, 12. Springer; 2014. p. 1129-56.

[39] T. Iwasaki, T. Arakawa, K.Tokida, Simplified Procedures for Assessing Soil Liquefaction During Earthquakes. In: Proceedings of Conference on Soil Dynamics \& EQ Engineering. Southampton; 1982, pp. 925-39.

[40] K. Ishihara, Stability of Natural Deposits during Earthquakes. In: Proceedings of the 11th International Conference on Soil Mechanics and Foundation Engineering, San Francisco, 1:321376; 1985. 